\title{
Upaya Hukum untuk Menjerat Tindakan Pelakor dalam Perspektif Hukum Adat Dayak Ngaju
}

\section{Putri Fransiska Purnama Pratiwi ${ }^{1}$, Suprayitno ${ }^{2}$ Triyani $^{3}$}

1 Putri Fransiska Purnama Pratiwi; Universitas Palangka Raya; Kampus UPR Tunjung Nyaho Jalan H. Timang; Palangka Raya; 73111A; Kalimantan Tengah; Indonesia.

2 Suprayitno; Universitas Palangka Raya; Kampus UPR Tunjung Nyaho Jalan H. Timang; Palangka Raya; 73111A; Kalimantan Tengah; Indonesia.

3 Triyani; Universitas Palangka Raya; Kampus UPR Tunjung Nyaho Jalan H. Timang; Palangka Raya; 73111A; Kalimantan Tengah; Indonesia.

ARTICLEINFO

Article history:

Received 2019-09-02

Received in revised form

2019-10-20

Accepted 2019-12-01

Kata kunci:

Dayak Ngaju; Hukum Adat;

Pelakor.

Keywords:

Dayak Ngaju; Customary Law;

Pelakor.

DOI: https://doi.org/10.26905/

idjch.v10i2. 3469.

\section{Abstrak}

Permasalahan yang terjadi adalah kekosongan hukum tentang pengaturan sanksi yang dapat dikenakan bagi Perebut Laki Orang (Pelakor) melalui jalur hukum nasional. Pada masyarakat adat Dayak Ngaju di Kalimantan Tengah sendiri telah diberlakukan sanksi Hukum Adat Dayak bagi masyarakat adat namun masih jarang diketahui oleh masyarakat suku Dayak sendiri. Penelitian ini menggunakan jenis penelitian yuridis empiris yang dilakukan dengan observasi dan wawancara di Lembaga Kedamangan dan Dewan Adat Dayak (DAD) di Kalimantan Tengah untuk mengisi kekosongan hukum bagi masyarakat Adat Dayak Ngaju di Kalimantan Tengah sebelum diberlakukannya RUU KUHP. Upaya hukum untuk menjerat perbuatan pelakor adalah dengan bersumpah, upaya paling serius dalam masyarakat adat suku Dayak Ngaju. Mereka percaya bahwa sumpah yang diucapkan pada saat Basara Adat akan berakibat fatal bagi pihak yang berani berbohong atau tidak mau mengakui perbuatannya yaitu memiliki umur pendek, tidak ada rejeki, penyakit tersu-menerus untuknya, keturunan serta saudara-saudaranya. Sanksi adat Dayak Ngaju yang dikenakan bagi perbuatan pelakoradalah membayar dua kali nilai palaku adat perkawinan (mahar) lelaki yang direbutnya membayar ganti rugi malu bagi keluarga wanita istri sah, ganti rugi biaya pernikahan bagi istri sah dan pesta damai.

\section{Abstract}

The problem that occurs is a legal vacuum regarding the regulation of sanctions that can be imposed on women who dare to tempt married men (Pelakor) through national law. In Dayak indigenous people in Central Kalimantan, the Dayak Custom- 


\section{Jurnal Cakrawala Hukum, Volume 10 No. 2 Desember 2019}

ISSN PRINT 2356-4962 ISSN ONLINE 2598-6538

ary Law is enforced firmly, but is still not widely known. This research uses a type of qualitative empirical research, conducted by visiting the Kedamangan Institutions in Central Kalimantan and Dayak Customary Council (DAD) in Central Kalimantan. It can complement the national legal effort before the national legal implementation of RUU KUHP for Dayak Ngaju community in Central Kalimantan. The legal effort taken to ensnare the cheating woman's action is the challenge of oath that is the most serious legal effort that can be conducted by the indigenous people of Dayak Ngaju tribe. They believe that the oath pronounced during the Basara Adat will be seriously for those who dare to lie. They might have a short life, no fortune and suffer from continuing illness for themselves and their descendants and siblings. Dayak Ngaju's custom sanctions imposed for Pelakor is to pay twice the value of the customary marriage (dowry) of a man he arrogated to pay shame compensation for the woman's wife's legal family, pay compensation for the marriage costs for the legal wife and pay for the party peace.

\section{Latar Belakang}

Perkawinan secara adat di kalangan masyarakat adat Dayak Ngaju dianggap suatu proses yang sakral. Perjanjian kawin berasal dari Ranying Hatalla sehingga dianggap sesuatu yang sangat suci. Jika terjadi pelanggaran terhadap perjanjian perkawinan tersebut maka pelanggar akan mendapat sanksi adat. Menurut Emile Durkheim pelanggaran tersebut sebagai suatu perbuatan yang mengakibatkan hukuman-hukuman dan pend'eritaanpenderitaan bagi pelanggarnya (Muhni, 1994).

Pelaksanaan perkawinan yang tidak sesuai dengan adat dan adanya perselingkuhan dipercaya akan membawa bencana karena telah melanggar janji kepada Ranying Hatalla Langit yang telah diikrarkan pada saat pemenuhan hukum adat. Walaupun masyarakat Dayak Ngaju di Kalimantan Tengah telah menganut berbagai agama berbeda seperti Islam, Kristen, Katolik dan Kaharingan. Tetap makna perkawinan pada prinsipnya adalah suatu kesepakatan yang suci dan tidak boleh dilanggar.

Ironisnya dewasa ini kasus perceraian di masyarakat Dayak Ngaju di Kalimantan Tengah. Khususnya di Kota Palangka Raya Kalimantan
Tengah berjumlah cukup banyak. Data di Pengadilan Agama Palangka Raya, sejak 2015 jumlah perceraian yang diajukan mencapai 390 perkara. Pada 2016, angka perceraian makin meningkat, di mana jumlah wanita janda mencapai 406 orang. Pada 2017 janda di Kota Palangka Raya sekitar 429 orang. Sementara itu, pria yang menduda di Palangka Raya juga meningkat. Pada 2015, suami yang berpisah dengan istrinya mencapai 112 orang. Pada 2016, pria menduda sekitar 124 orang. Sedangkan 2017 meningkat jadi 131 perkara (Kalteng Pos, 2018).

Berdasarkan penjelasan Panitera Muda Hukum Pengadilan Agama Palangka Raya Dyah Ayu Sekar Laela penyebab tingginya angka perceraian di Palangka Raya, dikarenakan faktor ekonomi perselingkuhan, kekerasan dalam rumah tangga, dan status pendidikan. Dari faktor-faktor tersebut yang lebih sering terjadi yakni perselingkuhan (Ibid).

Hal serupa juga disampaikan Kumpiady Widen. Dari pengamatannya, faktor dominan terjadinya kasus perceraian di Palangka Raya adalah selingkuh. Terkadang wanita juga bisa menggoda pria yang sudah memiliki istri. Kalau tidak 


\section{Upaya Hukum untuk Menjerat Tindakan Pelakor dalam Perspektif Hukum Adat Dayak Ngaju}

Putri Fransiska Purnama Pratiwi, Suprayitno, Triyani

kuat-kuat iman, pasti tergoda dan terjadilah perselingkuhan.

Istilah yang sedang popular di kalangan masyarakat terhadap wanita yang menggoda suami orang ini adalah 'Pelakor' atau singkatan dari 'perebut laki/lelaki orang'. Salah satunya adalah tentang Kasus Bupati Kasongan yang tertangkap tangan berselingkuh dengan istri orang lain. Perbuatan seperti ini telah melanggar nilai adat yang dipegang teguh oleh suku Dayak Ngaju di Kalimantan Tengah. Terlebih tersangka ini adalah seorang tokoh yang menjadi panutan masyarakat Dayak Ngaju di Kabupaten Katingan Kalimantan Tengah.

Kasus asusila seperti telah melanggar norma sosial dan falsafah Belum Bahadat suku Dayak Ngaju. Perbuatan ini dapat dikenai sanksi denda adat dengan tidak mengenyampingkan hukum positif dalam aspek pidana. Berdasarkan latar belakang tersebut penelitian ini akan mengkaji leibih dalam tentang Upaya Hukum Untuk Menjerat Tindakan Perebut Laki Orang (Pelakor) Dalam Perspektif Hukum Adat Dayak Ngaju.

\section{Metode}

Metode penelitian tentang Upaya Hukum Untuk Menjerat Tindakan Perebut Laki Orang (Pelakor) Dalam Perspektif Hukum Adat Dayak Ngaju menggunakan jenis penelitian empiris secara kualitatif. Penelitian ini bertujuan untuk memberikan pedoman bagi masyarakat adat Dayak Ngaju untuk menjerat dan memberikan efek jera bagi wanita Pelakor sesuai dengan hukum adat Dayak Ngaju untuk menjaga arti kesakralan pernikahan dalam adat Dayak Ngaju. Teknik pengumpulan data dilakukan dengan metode wawancara dan observasi, dokumen. Wawancara ini ditujukan untuk mengetahui upaya hukum yang selama ini dilakukan sesuai adat Dayak Ngaju dalam menjerat pelaku perselingkuhan terutama pasangan selingkuhnya agar menimbulkan efek jera di kemudian hari. Wawancara dilakukan di Lembaga-Lembaga Kedamangan sebagai pihak pertama dan Dewan Adat Dayak (DAD) di Kota Palangka Raya. Telaah dokumen dilakukan untuk mencari informasiinformasi yang terkait dengan permasalahan yang diangkat yang berasal dari dokumen-dokumen tertulis, yang berupa laporan-laporan dari masyarakat adat Dayak Ngaju tentang permohonan perceraian yang relevan dengan penelitian ini. Pengumpulan dokumen dilakukan dengan melihat data-data penyelesaian akhir kasus perselingkuhan yang disebabkan oleh Pelakor milik damang-damang adat di Kalimantan Tengah dan di Dewan Adat Dayak (DAD). Analisis data penelitian dilakukan dengan teknik deskriptif kualitatif Di dalam melakukan pengumpulan bahan hukum penulis menggunakan teknik studi perundang-undangan yaitu dengan meneliti berbagai peraturan perundang-undangan yang berhubungan dengan permasalahan yang penulis teliti. Kemudian dilakukan inventarisasi terhadap pasal dan ayat-ayat yang memiliki keterkaitan dengan permasalahan yang sedang diteliti.

\section{Pembahasan}

\subsection{Upaya Hukum yang dapat Dilakukan untuk} Menjerat Pelakor Melalui Jalur Hukum Adat Dayak Ngaju di Kalimantan Tengah

Hukum Adat Dayak Ngaju yang di berlakukan di Kalimantan Tengah berpedoman pada Hukum Adat Tumbang Anoi. Tumbang Anoi diambil dari sebuah nama desa di Kalimantan Tengah. Desa Tumbang Anoi menjadi saksi dari Rapat Damai Suku Dayak di tanggal 22 Mei hingga 24 Juli 1894, saat suku Dayak yang menetap di Kalimantan saling bertikai dan membunuh. Perjanjian ini dihadiri oleh setidaknya 1000 orang dan disepakati adanya 88 Pasal hukum adat dan 8 Pasal aturan kehidupan Belom Bahadat yang mengatur kehidupan suku Dayak agar tetap damai. Seluruh persoalan singer (denda) sebagai ganti pelanggaran diatur di dalam Hukum Adat Tumbang Anoi (Kumparan,2019). 


\section{Jurnal Cakrawala Hukum, Volume 10 No. 2 Desember 2019}

ISSN PRINT 2356-4962 ISSN ONLINE 2598-6538

Perbuatan merebut suami orang dalam Hukum Adat Dayak Ngaju disebut dengan Tungkun merupakan suatu perbuatan yang memiliki dimensi Pidana di dalamnya yaitu tergolong dalam Pelanggaran Adat Kesusilaan. Menurut Pedoman Peradilan Hukum Adat Kalimantan Tengah Pelanggaran Adat Kesusilana antara lain adalah: 1) Habandung (zinah) sama-sama suka; 2) Perkosaan, pelecehan seksual; 3) Tungkun (mengambil, merampas isteri/suami/calon isteri/calon suami orang lain); 4) Hamil di luar nikah (tulah/sumbang, sejajar, isteri orang lain, janda, bujangan dan sebagainya (Dewan Adat Dayak Provinsi kalimantan tengah, 2017).

Upaya Hukum yang dapat dilakukan untuk perbuatan hatungkun yaitu perbuatan seorang wanita yang merebut pria yang telah beristri dapat diadukan dengan cara melaporkan para pihak yang terlibat ke Damang Kepala Adat yang berkedudukan di wilayah kecamatan tempat tinggal si pelapor ataupun wilayah kedamangan tempat dilaksanakannya kawin adat para pihak yang terikat perkawinan tersebut. Salah satu prasyarat pengaduan adalah harus dilakukan dengan semangat kejujuran yang tinggi dari pihak yang merasa dirugikan dan memiliki niat yang tulus untuk memberikan maaf yang tulus kepada pelaku nantinya.

Jika semua bukti telah terkumpulkan serta para pihak yang dimaksud telah jelas keberadaannya maka akan digelarlah sebuah Basara Adat yaitu proses gelar perkara/persidangan dalam Sistem Hukum Adat Dayak Ngaju (Ibid). Basara Adat berdasarkan pada Peraturan Daerah Provinsi Kalimantan Tengah Nomor 16 Tahun 2008 tentang Kelembagaan Adat Dayak di Kalimantan Tengah memiliki ketentuan sebagai berikut: a) Jika basara adat itu berkenaan dengan pelaku yang melibatkan orang lain dari luar wilayah Kedamaagan (lintas wilayah yurisdiksi kedamangan) dalam satu wilayah kabupaten /kota, maka Damang dari wilayah hukum yang bersangkutan perlu memohon kepada Dewan Adat Dayak (DAD)
Kabupaten/Kota melibatkan Damang dari wilayah kedamangangan/kecamatan lain dalam menangani dan menyelesaikan perkara tersebut; b) Jika basara (gelar perkara) itu berkenaan dengan pelaku yang berasal dari luar kabupaten/kota (lintas kabupaten/kota), maka Damang Kepala Adat dari wilayah hukum yang bersangkutan perlu memohon kepada Dewan Adat Dayak (DAD) Provinsi untuk melibatkan Damang Kepala Adat dari Kabupaten/ Kota lain di wilayah provinsi yang bersangkutan Let (hakim) Adat; c) Jika basara (gelar perkara) itu berkenaan dengan pelaku yang berasal dari luar provinsi (lintas provinsi), maka Damang Kepala Adat dari wilayah provinsi bersangkutan perlu memohon kepada Majelis Adat Dayak Nasional (MADN) menugaskan Damang Kepala Adat dari provinsi lain itu untuk menjadi Let (hakim) Adat.

Proses penyelesaian kasus Hatungkun (Wawancara Damang Kardinal Tarung pada 09 Agustus 2019) menurut Hukum Adat Dayak Ngaju bertujuan untuk menghindari adanya perceraian. Sesuai dengan dasaran dilaksanakannya basara adat (gelar adat) yaitu untuk "Nantilang Sial Kawe Mampataduh/ Mampatende Karidu Kalait (menetralisir aspek kesialan menciptakan ketentraman magis)".

Proses penyelesaian secara Hukum Adat terhadap pelaku Hatungkun dalam hukum Adat Dayak Ngaju, langkah-langkah yang perlu ditempuh adalah sebagai berikut: Pemanggilan pihakpihak yang bersengketa Setelah adanya pengaduan, pihak mantir adat segera menyiapkan surat panggilan kepada pihak terlapor. Surat panggilan dimaksud diberitahukan kepada pelapor dan damang sebagai tembusan. Adapun tata cara pemanggilannya (Wawancara Damang Jekan Raya Kardinal Tarung 08 Juli 2019) adalah sebagai berikut: 1) Pemanggilan kepada pihak terlapor maksimal (1) satu minggu setelah diterimanya pengaduan. Panggilan ini adalah merupakan panggilan yang pertama. 2) Apabila panggilan pertama diabaikan oleh terlapor, maka akan disampaikan panggilan yang kedua, waktunya maksimal (1) satu 


\section{Upaya Hukum untuk Menjerat Tindakan Pelakor dalam Perspektif Hukum Adat Dayak Ngaju}

Putri Fransiska Purnama Pratiwi, Suprayitno, Triyani

bulan setelah panggilan yang pertama. 3) Apabila pihak terlapor tetap saja tidak datang untuk memenuhi panggilan yang kedua, maka akan disampaikan panggilan yang ketiga atau yang terakhir, dimana dalam surat panggilan yang terakhir ini ditegaskan penyelesaian atau Basara Adat akan dilaksanakan pada tanggal yang telah ditetapkan dan apabila dalam Basara Adat tersebut yang bersangkutan tidak datang, maka segala keputusan Damang atas masalah tersebut, dianggap diterima oleh yang bersangkutan. 4) Setiap surat panggilan harus disertai dengan tanda terima panggilan yang ditandatangani oleh yang bersangkutan dan apabila yang bersangkutan tidak berada ditempat maka tanda terima dimaksud harus ditandatangani oleh keluarga atau orang tuanya. Penetapan tanggal Basara Adat dan pemberitahuan kepada para saksi Setelah pihak yang dipanggil atau perwakilannya mau datang ke mantir Adat, maka pihak mantir adat akan menetapkan tanggal sidang setelah mendapat persetujuan pihak yang melaporkan. Tanggal sidang ditetapkan paling lama satu minggu setelah pihak yang dilaporkan melaporkan diri ke Mantir Adat. Kedatangan terlapor ini harus dibuatkan surat tanda melaporkan diri yang ditandatangani oleh Mantir Adat. Tanggal sidang ini nantinya akan diberitahukan oleh Mantir Adat secara tertulis kepada para pihak yang bersangkutan. Dalam surat pemberitahuan tersebut, dilampirkan formulir kesediaan para saksi untuk hadir dalam sidang, yang disampaikan pihak yang bersengketa langsung kepada para saksi masingmasing. Surat kesediaan ini nantinya harus dibawa dalam Basara Adat pertama.

Penyelenggaraan Basara Adat Pelaksanaan Basara Adat terhadap pelaku Habandung dalam hukum Adat maksimal dilakukan tiga kali oleh para Mantir Adat. Keputusan harus dibuat secepatnya pada Basara Adat yang pertama atau yang kedua. Apabila keputusan, tidak dimungkinkan pada kedua Basara Adat tersebut, maka pada Basara Adat ketiga harus ada keputusan.
Penundaan keputusan pada Basara Adat yang pertama biasa dilakukan apabila para saksi tidak hadir. Apabila para pihak dalam Basara Adat yang ketiga ini masih tidak mau menerima rancangan keputusan yang dibuat, maka perkara tersebut diserahkan penyelesaiannya kepada damang yang berada dilingkup kecamatan tersebut, dengan waktu penyampaiannya paling lama satu minggu.

Penyerahan perkara kepada Damang disampaikan secara tertulis dengan melampirkan berbagai dokumen yang telah disertakan dalam kerapatan mantir perdamaian Adat. Namun demikian, penyerahan perkara ke Damang baru bisa dilakukan apabila masing- masing pihak mempunyai bukti atau saksi yang kuat. Apabila hanya didasarkan pada sikap keras hati, ngotot, tidak mau mendengar pendapat orang lain, maka sebaiknya keputusan diambil oleh para Mantir Adat paling lambat dalam sidang yang ketiga.

Penyelesaian perkara oleh Damang Kepala Adat Waktu penyelesaian perkara oleh damang kepala Adat dilakukan maksimum dua bulan, dalam dua kali sidang. Sidang dilakukan di desa asal perkara yang dihadiri oleh para Mantir Adat dan para saksi yang telah hadir dalam sidang pertama hingga sidang yang ketiga dalam kerapatan Mantir perdamaian Adat. Sidang pertama adalah mendengarkan keterangan pihak yang berperkara dan para saksi. Apabila ternyata tidak diperlukan komisi (peninjauan objek sengketa/permasalahan), maka keputusan harus diambil dalam sidang yang pertama.

Tata urutan Basara Adat terhadap Pelaku Habandung dalam Hukum Adat Dayak Ngaju Tata urutan acara persidangan oleh mantir Adat dan Damang dilakukan sebagai berikut: Pembukaan, yaitu pernyataan oleh Mantir Adat dan atau Damang mengenai Basara Adat yang akan dilaksanakan pada saat itu. Adapun hal-hal yang akan disampaikan adalah: 1) Identitas pihak pelapor dan terlapor; 2) Objek perkara/permasalahan yang dipersoalkan; 3) Penegasan kepada para pihak yang bersengketa 


\section{Jurnal Cakrawala Hukum, Volume 10 No. 2 Desember 2019}

ISSN PRINT 2356-4962 ISSN ONLINE 2598-6538

dan para saksi untuk berkata jujur dalam Basara Adat, sebagai gambaran dari cita sebagai manusia yang "Belom Bahadat".

Prosedur penyelesaian perkara secara garis besar (Wawancara Dengan Ketua Dayak Hindu Kaharingan Kota Palangka Raya Parada L. KDR pada 12 April 2019) dilakukan dengan melakukan pengaduan yang dapat dilakukan oleh istri sebagai korban, anak, keluarga, masyarakat, RT, RW atau bahkan saksi mata yaitu membuat surat permohonan yang berisikan pengaduan yang ditujukan kepada Damang selaku Kepala Adat dan Mantir sebagai pelaksana untuk segera di proses.

Setelah melihat bukti dan saksi yang ada, maka diadakan musyawarah yang bertujuan untuk berembuk mencari kebenaran dan keputusan akhir dari kasus tersebut setelah itu diadakanlah basara adat untuk memutuskan sanksi/denda bagi yang bersalah dan pembacaan singer/denda yang diberikan kepadanya.

Pengambilan sumpah Adat (bukan sumpah menurut agama) dari pihak yang bersengketa dan juga para saksi. Dalam sumpah Adat ini perlu dilakukan oleh tukang tawur/pisur yang terlebih dahulu memanggil roh-roh untuk memberikan kekuatan dan kemampuan untuk berkata jujur. Pengambilan keterangan dari pihak-pihak yang bersengketa dan juga keterangan dari para saksi maka dilakukan pembacaan kesimpulan oleh Mantir Adat atau Damang atas keterangan para pihak yang bersengketa dan juga saksi.

Dalam hal telah dilakukan diskusi, maka hasil dari peninjauan objek perkara/permasalahan juga disampaikan, atau apabila akan ada peninjauan maka hal tersebut juga disampaikan/dirundingkan, dengan waktu paling lama tiga hari. Pemberhentian Basara Adat untuk beberapa waktu (maksimal satu jam) oleh Mantir Adat atau Damang, untuk memberikan kesempatan pada mereka untuk berunding mengenai rancangan keputusan.

Dalam perundingan ini juga dibicarakan pasal hukum Adat yang dilanggar oleh pihak yang berperkara terutama pihak yang dianggap melanggar hukum Adat dengan mengacu pada 96 pasal hukum Adat hasil perjanjian Tumbang Anoi. Penyampaian rancangan keputusan, dalam kesempatan dibicarakan juga pasal hukum Adat yang telah dilanggar dan sanksi Singer (denda Adat) yang akan dibayar oleh pihak yang elah melanggar ketentuan di dalam Hukum Adat Dayak Ngaju.

Penyampaian tanggapan dari para pihak yang bersengketa atas rancangan keputusan yang disampaikan oleh Mantir Adat atau Damang dalam penyelesaian perkara tersebut. Pengambilan keputusan oleh Mantir Adat atau Damang atas perkara yang terjadi serta pembuatan berita acara Sidang penyelesaia perkara dan penandatanganan keputusan yang dikeluarkan atas perkara tersebut. Upacara perdamaian yaitu berupa tampung tawar, penyembelihan hewan, pesta dan atau Hasapa.

Dalam hal hasapa ini hanya dilakukan pada tingkat perkara yang ditangani oleh Damang dan jika dalam suatu perkara tidak ada yang berkata jujur untuk mengakui kesalahannya sehingga permasalahan tidak menemukan titik penyelesaian.

Tata cara pengambilan sumpah Adat para pihak yang bersengketa dan para para saksi Sumpah adat dilakukan dengan tidak memandang agama yag dianut oleh para pihak yang yang bersengketa yaitu pelapor dan terlapor serta para saksi. Sumpah Adat ini di ambil atau di pimpin oleh tukang Tawur Pisur atau Basir Balian yang merupakan pakar dari suatu kepercayaan masyarakat Adat Dayak Ngaju atau Ahli Agama terdahulu Orang Dayak. Adapun sumpah Adat tersebut beerisi hal-hal sebagai berikut: 1) Memberikan keterangan dengan benar dan sejujur jujurnya; 2) Menyatakan bahwa yang bersangkutan menyumpah dirinya sendiri dan bersedia menanggung segala dampak yang akan terjadi dalam hidupnya apabila dia berkata lain dari kebenarannya yaitu: pandak Umur, Dia Atun Rajaki, Kana Haban Kapehe Sambung Sambunga Akan lye Kabuat Dan Kare 


\section{Upaya Hukum untuk Menjerat Tindakan Pelakor dalam Perspektif Hukum Adat Dayak Ngaju}

Putri Fransiska Purnama Pratiwi, Suprayitno, Triyani

Arnak Jaria, Kawan Pahariyang artinya memiliki umur pendek, tidak ada rejeki, sakit penyakit yang sambung menyambung untuknya, keturunan serta saudara-saudaranya. Kemudian enyatakan akan menerima segala keputusan yag dibuat degan hati lapang dan tidak memelihara dendam dan akan melakukan kewajibannya sesuai keputusan yang akan diambil.

Upaya hukum yang dilakukan dengan tantangan bersumpah adalah upaya hukum paling serius yang dapat dilakukan oleh masyarakat adat suku Dayak Ngaju untuk membuktikan ada tidaknya niat jahat dalam diri si pelakor. Akibat dari sumpah yang diucapkanlah yang amat ditakuti jika terjadi di kemudian hari. Mereka percaya bahwa sumpah yang diucapkan pada saat basara adat telah didengar oleh semua elemen yaitu Tuhan, alam, manusia maupun roh-roh nenek moyang sehingga akan berakibat fatal bagi kehidupan si pelanggar smaupun pihak yang berani berbohong dalam ikrar sumpah tersebut. Dalam hal ini tindakan pengambilan sumpah menjerat Pelakor dianggap sesuai karena merupakan perbuatan hina yang mencerminkan sikap Belom Dia Bahadat, karena berani menggoda atau merebut suami orang lain.

\subsection{Sanksi Adat Bagi Pelakor Berdasarkan Hukum Adat Dayak Ngaju di Kalimantan Tengah}

Salah satu ciri khas dari Hukum Adat Dayak Ngaju berdasarkan (Wawancara Dengan Damang Pahandut Marcos Tuan Tanggal 04 Mei 2019) memiliki hakekat bukan untuk menghukum tetapi untuk menyelesaikan masalah. Tidak untuk saling menyakiti/ merugikan pihak yang bersengketa namun menyelesaikan masalah, memperbaiki kerusakan diantara mereka. Pihak yang berperkara diharapkan pada akhirnya dapat menjadi saudara. Hal ini bertujuan untuk mengembalikan keseimbangan alam serta memberikan pendidikan hukum kepada seluruh anggota masyarakat hukum adat termasuk orang asing yang berdomisili diKalimantan Tengah sendiri.
Ancaman dan pengenaan sanksi bukan hanya pada manusia tapi pada hewan dan juga lama semesta, sekalipun pelaksanaanya dikerjakan oleh manusia melalui ritual. Sehingga sanksi-sanksinyapun ditujukan untukmendamaikan pihak yang sedang berperkara. Menyelesaikan masalah, mengembalikan keseimbangan alam baik hubungannya dengan alam, manusia dan sang pencipta.

Berdasarkan ketentuan Pasal 32 Peraturan Daerah Provinsi Kalimantan Tengah Nomor 16 Tahun 2008, disebutkan jenis-jenis sanksi dapat dikategorikan sebagai berikut: 1) Sanksi Ringan berupa: a) Nasihat; b) Teguran; c) Pernyataan maaf. 2) Sanksi sedang adalah Singer (ganti rugi) dan denda berdasarkan kearifan lokal. 3) Sanksi Berat, yakni: a) Dikucilkan; b) Dikeluarkan dari masyarakat adat (diusir); c) Pencabutan gelar.

Berbagai jenis sanksi singer di masyarakat dapat dikelompokkan menjadi 3 (tiga) kelompok, yaitu: 1) Dendangganti kerugian dlam berbagai rupa seperti pembayaran uang adat kepada orang yang terkena, menyerahkan barang adat seperti guci, gong, mandau atau tombak sebagai pengganti kerugian rohani. 2) Denda melaksanakan upacara adat (dengan mengorbankan hewan babi, ayam, sapi, atau kerbau) untuk pembersihana batin si korban, membersihkan masyarakat dari segala aib (hal-hal yang tabu) sebagai bentuk permohonan maaf si pelaku kepada para leluhur secara rohaniah. 3) Denda pengasingan (dikucilkan) dari masyarakat di luar tata hukum, bentuk pertanggung jawaban secara batiniah si pelaku atas pelanggaran adat yang dilakukannya.

Suku Dayak Ngaju di Kalimantan Tengah mengenal istilah sanksi adat dengan sebutan Jipen. Jipen adalah denda atau sanksi adat yang dijatuhkan oleh Damang Kepala Adat berdasarkan kesepakatan musyawarah sesuai dengan isi pasal Hukum Adat Dayak Ngaju bagi warga yang melakukan kesalahan maupun menyalahi adat penduduk setempat. Jipen bentuk dan besarannya berbeda-beda sesuai dengan pelanggaran yang dila- 


\section{Jurnal Cakrawala Hukum, Volume 10 No. 2 Desember 2019}

ISSN PRINT 2356-4962 ISSN ONLINE 2598-6538

kukan oleh orang itu (Wawancara Mantir Adat Jekan Raya Suparan A.Gaman, 10 Agsutus 2019).

Dalam manjalankan tugasnya Damang Kepala Adat dibantu oleh mantir adat selaku ketua adat di tingkat desa/kelurahan. Sejumlah kasus pelanggaran hukum adat baik yang dilakukan masyarakat asli maupun masyarakat pendatang di Kalimantan Tengah diselesaikan melalui sebuah persidangan adat. Persidangan adat itu di pimpin oleh tokoh adat (Damang) dan dipercaya diawasi oleh roh para leluhur (Ibid).

Sidang adat berisi ritual-ritual sebelum dilakukannya sidang sebagai tanda dimulainya peradilan adat. Proses peradilan dilaksanakan seperti musyawarah, duduk berkelompok di dalam ruangan untuk berembuk mencari keputusan ysng tepat terhadap kasus yang terjadi. Selanjutnya pria dan wanita yang terlibat disumpah secara adat. Sumpah ini mempunyai konsekuensi berakibat fatal apabila dilanggar atau terdakwa memberi keterangan yang tidak benar/berbohong. Karma dari sumpah inilah yang sangat diyakini dan ditakuti masyarakat suku Dayak Ngaju.

Sanksi dari perbuatan pelakor atau yang disebut dengan bahasa Dayak Ngaju adalah terdapat dalam Pasal 1 Perjanjian Tumbang Anoi dan diterapkan pada salah satu kasus yang penulis dapatkan pada Kedamangan Jekan Raya Palangka Raya yaitu kasus Pelakor (Hatungkun). yaitu dalam Surat Keputusan Damang Kepala Adat Kecamatan Jekan Raya Nomor: 003/DKA-KJR/BA-HPPA/II/ 2018 tentang Berita Acara Perkaar Adat Hatulang Belum dan Tungkun terhadap ELSI PANIA sebagai penggugat yang menggugat suaminya DWI RYANANDA dan seorang wanita bernama MAYA KUMALASARI yang diduga sebagai penggoda/ perebut suaminya. Pasal 1 Singer Tungkun (denda adat merampas istri orang lain) dikenakan pada barangsiapa yang berani membujuk, merampas istri atau suami orang lain sehingga akibatnya pria/ wanita itu cerai dengan suami/istri yang terdahulu dan kawin dengan wanita/pria baru yang menungkun. Contoh: A berani mengambil wanita/pria B, suami/istri C. Singer Tungkun dapat dikenakan pada A. Ancaman singer tungkun, Sanksi adat dayak ngaju yang dikenakan bagi perbuatan Pelakor untuk perbuatannya berani merebut suami orang adalah: a) Membayar Dua kali nilai palaku adat perkawinan (mahar) lelaki yang direbutnya; b) Membayar Lima belas kati ramu tekap bau mate (penutup malu) bagi keluarga wanita istri sah; c) Memberikan Pakaian sinde mendeng (satu stel pakaian) bagi wanita istri sah; d) Membayar ganti rugi biaya pesta kawin yang dikeluarkan istri sah sekeluarga; e) Menanggung biaya pesta perdamaian adat khusus (makan-minum bersama, memotong dua ekor babi bagi alam dan masyarakat setempat).

\section{Simpulan}

Upaya hukum yang dilakukan dengan tantangan bersumpah adalah upaya hukum paling serius yang dapat dilakukan oleh masyarakat adat suku Dayak Ngaju dalam pembuktian ada tidaknya niat jahat dalam diri si pelakor. Perbuatan pelakor dianggap hina mencerminkan sikap Belom Dia Bahadat, Akibat dari sumpah yang diucapkanlah yang amat ditakuti jika terjadi di kemudian hari. Sumpah tersebut berisi pernyataan bahwa yang bersangkutan menyumpah dirinya sendiri dan bersedia menanggung segala dampak yang akan terjadi dalam hidupnya apabila dia berkata lain dari kebenarannya yaitu: Pandak Umur, Dia Atun Rajaki, Kana Haban Kapehe Sambung Sambunga Akan lye Kabuat Dan Kare Arnak Jaria, Kawan Pahari yang artinya memiliki umur pendek, tidak ada rejeki, sakit penyakit yang sambung menyambung untuknya, keturunan serta saudara-saudaranya. Sanksi adat dayak ngaju yang dikenakan bagi perbuatan Pelakor untuk perbuatannya berani merebut suami orang lain lebih dititik beratkan kepada kepentingan istri sah yaitu denda pengganti baiaya yang telah dikeluarkan keluarga istri untuk pernikahannya, denda kebutuhan sehari-hari istri, denda pemulihan nama baik istri dan biaya pesta perdamaian bagi keluarga besar. 


\section{Daftar pustaka}

Anonim. 2018. Dari: http://kaltengpos.web.id/ detail_berita/berita-1051 wow\%E2\%80\% A6di_ palangka_raya_ternyata_banyak_janda.html. 18 Agustus 2018.

Anonim. 2019. Dari: https://kumparan.com/ @kumparannews/hukum-adat-dayak-menantipasangan-bupati-katingan-dan-selingkuhannya. 27 Agustus 2019.

Dewan Adat Dayak Provinsi Kalimantan Tengah. 2017. Hadat 1894-Melihat Kembali 96 Pasal Hukum Adat dan Praktiknya Dalam Kehidupan Masyarakat Adat Dayak. Jakarta. Bumi Tama Gunajaya Agro.
Kuena. 2015. Simbol Dalam Upacara Adat Dayak Ngaju. Jurnal Bahasa, Sastra dan Pembelajarannya Vol.5 No. 2 (2015). https://ppjp.ulm.ac.id. 04 Oktober 2019.

Muhni, D. A.I. 1994. Moral dan Religi Menurut Emile Durkheim \& Henri Bergson. Yogyakarta. Kanisius.

Normuslim. 2018. Kerukunan Antar Umat Beragama Keluarga Suku Dayak Ngaju di Palangka Raya. Wawasan:Jurnal Ilmiah Agama dan Sosial Budaya. 3, 1 (Juni 2018). http://www.researchgate.net. 04 Oktober 2019.

Putri Fransiska Purnama Pratiwi. 2019. Juridicial Review of Pelakor In Criminal Law Perspective. Morality: Jurnal Ilmu Hukum. Vol.5 No. 1 (2019). https:// jurnal.upgriplk.ac.id. 01 September 2019. 